POLITYKA ENERGETYCZNA - ENERGY POLICY JOURNAL

$2019 \uparrow$ Volume $22 \uparrow$ Issue $3 \uparrow 19-32$

DOI: $10.33223 /$ epj/111987

Waldemar DOŁĘGA ${ }^{1}$

\title{
Selected aspects of national economy energy efficiency
}

ABSTRACT: In this paper, selected aspects of energy efficiency are shown. The European Union regulations in area of energy efficiency such as Directive 2012/27/EU, are discussed. The national legal regulations which describe energy efficiency such as the Energy Efficiency Act are presented. Principles concerning the obligation of energy savings and energy audits of enterprises are described. National, regional and local programs and measures concerning the improvement of energy efficiency are performed. These are horizontal measures and energy efficiency measures in: industry, transport, the buildings of public institutions and energy generation and supplies. National economy energy efficiency is shown. The energy intensity indicators (primary, final) and rate of their changes in last years are performed. Moreover, directions of undertakings connected with the possible future reduction in energy intensity of the national economy, are defined. An analysis of energy efficiency measures and solutions for the improvement of energy efficiency, especially in industry and households, is performed. The improvement of economy energy intensity indicators constitutes the most effective solution which brings significant economic, technical and environmental benefits such as an increase in economic innovation and its competitiveness, the improvement of the energy supply security level, a reduction in the consumption of natural resources and a reduction of air pollution and greenhouse gas emissions. The conclusions contain an analysis of the present level of energy efficiency in Poland and the perspectives of its increase in the future along with the benefits connected with it.

KEYWORDS: energy efficiency, economy, energy intensity, energy policy

$\triangle$ Corresponding Author: Waldemar Dołęga; e-mail: waldemar.dolega@pwr.edu.pl

1 Wrocław University of Technology, Wrocław, Poland; ORCID iD: 0000-0003-2878-1358; e-mail: waldemar. dolega@pwr.edu.pl

2019. The Author(s). This is an open-access article distributed under the terms of the Creative Commons Attribution-ShareAlike International License (CC BY-SA 4.0, http://creativecommons.org/licenses/by-sa/4.0/), which permits use, distribution, and reproduction in any medium, provided that the Article is properly cited. 


\section{Introduction}

Energy efficiency (EE) is strictly connected with a sphere of energy use and consumption and has an influence on such energy elements as: delivery, security, prices, savings and environmental aspects (e.g. greenhouse gases (GHG) emissions). Moreover, EE has a considerable influence on macroeconomic impacts, industrial productivity, public budgets, disposable income, employment, resource management and health and well-being, (IEA 2016). In Polish conditions, EE is very important, among other things, for increasing productivity and the competitiveness of national enterprises both on the international and national market and ensuring the security of the energy supply and environmental safety. Due to this reason, energy efficiency improvement of the national economy is one of the strategic goals of the national economic policy in the area of energy (Dołęga 2017). Progress in a field of EE is vital for reaching all the objectives of the energy policy and also for more objectives of the environment and climate policy (Dołęga 2017). The current EE objective, which is at the same time one of the three main Polish national 2020 targets, is an iincrease of energy efficiency in 2020 by 20\%, as compared to 2005 (EPP 2010). Different targets are a 15\% share of energy generated from renewable energy sources (RES) in the total primary energy and $\mathrm{CO}_{2}$ emissions reduction by $20 \%$, with respect to 1990 levels (EPP 2010).

In last national strategic government document connected with energy policy - the draft "Energy Policy of Poland until 2040", the EE objective for 2030 was defined as a reduction of energy consumption at level of $23 \%$, relative to the forecasts for 2030 , as a result of energy efficiency improvement (EPP 2018). Different targets for 2030, which were stipulated in this draft, constituted $21 \%$ share of energy generated from RES in the total primary energy and $\mathrm{CO}_{2}$ emissions reduction by 30\% (EPP 2018).

\section{The European Union regulations}

The domain of energy efficiency is the focus of attention of the European Union (EU) (Dołęga 2018). The EU Commission regards energy efficiency as a strategic priority for the Energy Union. Moreover, they introduced the principle of energy efficiency first (BEP 2015). This is connected to the fact that the more efficient use of energy leads to: the reduction of energy demand, increase of energy security, lower energy bills for consumers, lower emissions of GHG and other pollutants, reduction of the need for the expansion of energy infrastructure, etc. (BEP 2015). Additionally, energy efficiency contributes to substantial savings in energy consumption.

The first EU document connected with the sphere of energy efficiency was Directive 2006/32/ EC of the European Parliament and of the Council of 5 April 2006 on energy end-use efficiency 
and energy services and repealing Directive 93/76/EC (Directive 2006). The general objective of this document was the achievement of energy savings at the level of $9 \%$ in the ninth year of the application of the directive. It was the national indicative energy saving goal which, for Poland, meant an obligation to save $9 \%$ of the primary energy by 2016 , among others through energy services and other means of improving energy efficiency (NEEAP 2014).

The last and main EU document in the domain of energy efficiency is Directive 2012/27/ EU of the European Parliament and of the Council of 25 October 2012 on energy efficiency, amending Directives 2009/125/EC and 2010/30/EU and repealing Directives 2004/8/EC and 2006/32/EC (Directive 2012). This directive established a common framework of measures for the promotion of energy efficiency in the EU countries in the context of the Union's 2020 target achievement in area of energy efficiency and future (beyond that date) undertakings for energy efficiency improvements (Directive 2012). It described the requirements and rules which let barriers in the energy market to be removed and market failures that impede efficiency in the supply and use of energy to be overcome. It also provides for the establishment of indicative national energy efficiency targets for 2020 (Directive 2012). One of the mentioned directive aims was the reduction of the domestic consumption of primary energy in the period of 2010-2020 by 13.6 Mtoe and the achievement of primary and final energy consumption in 2020 on level of 96.4 and 71.6 Mtoe respectively (NEEAP 2014).

\section{National regulations}

The Energy Efficiency Act (in short the EE Act) is the fundamental national legal act in the area of energy efficiency and constitutes implementation of the Directive 2012/27/EU provisions on national level (Act EEL 2016). It is the third version of the Energy Efficiency Act, but was substantially amended in 2018 and 2019. The first EE Act was passed in 2011 (Act EEL 2011).

The EE Act applies to electric energy, heat and natural gas and defines: the principles of carrying out the duty of energy savings, the rules for conducting audits of energy enterprises, the EE tasks for public sector entities and the principles of developing a national energy efficiency action plan (Act EEL 2016). Moreover, this act introduces systemic solutions enabling a decrease in the supply of fuels and energy, and an increase in the efficiency of energy use by ultimate consumers (Act EEL 2016).

The EE Act provisions apply to: energy enterprises, public sector entities and the ultimate consumers of energy carriers. Energy enterprises are obliged to carry out specific undertakings within their organization or undertakings aimed at improving the end user energy efficiency, resulting in final energy savings in the amount specified in the EE Act, confirmed by an energy efficiency audit or to obtain energy efficiency certificates and submit them to the President of Energy Regulatory Office (in short the President of ERO) for redemption (Dołega 2018). The savings are expressed in tonnes of oil equivalent (toe), where 1 toe means an equivalent of one 
tonne of crude oil with a calorific value of $41.868 \mathrm{MJ} / \mathrm{kg}$ (Dołęga 2018). Their size is set at 1.5\% per annum and refers to the amount of natural gas, heat or electricity sold in a given year to end users connected to the network less the amount of energy saved by the end users (Act EEL 2016).

The EE Act defines an EE support mechanism based on a system of energy efficiency certificates (the so-called white certificates), with transferrable proprietary rights, bearing the value of the declared energy effect expressed in toe (Dołęga 2018). Such certificates can be firstly obtained the undertakings characterized by the highest economic effectiveness which are selected through a tender announced by the President of the ERO. The parameter deciding the selection of tender offers is the value of the energy effect. It represents a ratio of the average amount of energy saved per annum as a result of carrying out an undertaking or a group of undertakings aimed at improving energy efficiency, to the energy efficiency certificate value (Report PERO 2019). The successful bids are those for which the above effect is within a specified range, and certificates are issued in the order corresponding to the value of the declared energy effect.

Tenders organized by the President of the ERO give the energy enterprises which conduct their activity in area of the generation, transmission or distribution of electric energy possibilities obtaining white certificates for carried out energy-saving undertakings.

The support mechanism of energy efficiency can also be used by all consumers of energy carriers (natural gas, electric energy, heat) but a chance of obtaining an energy efficiency certificate concerns EE undertakings characterized by an energy saving amounting to 10 toe per annum (Act EEL 2016).

According to the EE Act, the following kinds of undertakings particularly contribute to EE improvement: the alteration or renovation of buildings with their technical systems and equipment; the modernization of: household appliances, lighting and house auxiliaries; the insulation of industrial installations; the recovery of energy from industrial processes; the modernization of: industrial process equipment and installations, the modernization of: local heat networks and sources; the limitation of losses in transmission and a distribution network (electric power, gas, heat); the reduction of reactive energy intake losses; the limitation of losses in electric power transformers, the reduction of losses connected with systems supplying telecommunications or computer equipment, etc.; the use of energy generated in RES installations, or useful heat generated as part of highly efficient cogeneration (Dołęga 2018).

The energy efficiency certificate constitutes a confirmation of the planned amount of final energy to be saved owing to an EE undertaking or a group of such undertakings. The energy efficiency audit, which is precisely defined and specified in the EE Act is closely connected with the latter. The audit document contains an energy consumption analysis, a description of the condition of a facility, technical equipment or an installation, a list of measures aimed at improving the energy efficiency of the facility, the technical equipment or the installation and an evaluation of the viability of the measures and the achievable energy savings (Dołęa 2018). This is a document indispensable for the entity in which an energy efficiency improvement undertaking or a group of such undertakings are to be carried out or which has completed an energy efficiency improvement undertaking or a group of such undertakings (Dołęga 2017). In the former case, it is particularly important to specify the energy savings to be obtained while in the latter case, 
the effects yielded by the completed undertaking or the group of undertakings and the achieved energy savings need to be specified.

The EE Act describes the rules and the procedure of the enterprise energy audit for large and very large enterprises which comprises comprehensive analyses and calculations concerning proposed energy efficiency improvement undertakings, carried out every four years to supply information about the potential energy savings (Dołega 2017). The audit contains, among others, a detailed survey of energy consumption in industrial installations, in buildings (building complexes), and in transport, altogether responsible for at least $90 \%$ of the total energy consumption by the enterprise (Act EEL 2016). The procedure of the enterprise energy audit does not apply to microentrepreneurs and small and medium-sized entrepreneurs (Act EEL 2016).

Moreover, the EE Act introduces an obligation for the public sector to serve as a role model in energy savings and to use energy rationally. Central and local government units have been obligated to use one of the energy efficiency measures from the list included in the EE Act in carrying out their tasks. The means are mainly connected with low operating costs, low energy consumption level, thermal upgrading or an environmental management system (Dołęga 2018).

Energy efficiency policy in Poland is defined in several national strategic law regulations such as: strategies, policies and action plans. The key documents are: Poland's Energy Policy until 2030 (EPP 2010) and National Energy Efficiency Action Plans. The last action plan adopted in 2018 - Fourth Action Plan on energy efficiency (NEEAP 2017) describes the achieved goals of energy efficiency improvement, the objectives in area of energy efficiency for 2020 and the planned means and measures necessary for the achievement of the EE's objectives (NEEAP 2017).

\section{Support programs and measures}

The EE Act, as mentioned above, defines the statutory systemic support in area of energy efficiency. This support is complemented by national, regional and local programs and measures of efficiency improvement. They are mainly connected with support the funding of EE actions and enable to obtain a financial support for such investments and actions as: enterprise energy audits, energy-saving equipment and technologies, investments leading to a reduction in energy consumption in enterprise energy management or increasing the share of renewable energy and technical projects leading to the implementation of an energy efficiency improvement undertaking (NEEAP 2017).

The financial support mechanisms, systems, programs and measures used for efficiency improvement are often similar to those for renewable energy sources (Dołęga 2017). But there are also other solutions dedicated only for area of energy efficiency.

Basically, the energy efficiency improvement programs and measures existing in Poland comprise five groups of means: measures having a horizontal nature, and measures connected with respectively the energy efficiency of buildings and public institutions, energy efficiency 
in industry, energy efficiency in transport, and the efficiency of energy generation and supply (NEEAP 2017). Table 1 shows the names of programs and measures for each characterized group. The second group is the most numerous.

TABLE 1 . The energy efficiency improvement programs and measures existing in Poland

TABELA 1. Programy i środki poprawy efektywności energetycznej istniejące w Polsce

\begin{tabular}{|c|c|}
\hline Group of measures & Name of programs and measures \\
\hline Horizontal measures & $\begin{array}{l}\text { Energy efficiency certificates scheme (white certificates); } \\
\text { The Operational Program Infrastructure and Environment 2014-2020 - Nation- } \\
\text { wide system of advisory support in the field of energy efficiency and RES for the } \\
\text { public, housing and enterprise sectors; }\end{array}$ \\
\hline $\begin{array}{l}\text { Measures connected with } \\
\text { the energy efficiency } \\
\text { of buildings and public } \\
\text { institutions }\end{array}$ & $\begin{array}{l}\text { The Thermomodernization and Repairs Fund; } \\
\text { The Operational Program - Saving energy and promoting renewable energy so- } \\
\text { urces; } \\
\text { Green Investments Scheme Part } 1 \text { - Energy management in public utility faci- } \\
\text { lities, Part } 5 \text { - Energy management in the facilities of selected public finance } \\
\text { sector entities and Part } 6 \text { - SOWA - Energy Efficient Street Lighting; } \\
\text { The Operational Program Infrastructure and Environment 2014-2020 (Invest- } \\
\text { ment Priority) - Supporting energy efficiency in: public buildings, the housing } \\
\text { sector and residential buildings (Silesia Province); } \\
\text { Regional operational programs for 2014-2020. }\end{array}$ \\
\hline $\begin{array}{l}\text { Measures connected } \\
\text { with energy efficiency in } \\
\text { industry }\end{array}$ & $\begin{array}{l}\text { Support for entrepreneurs as regards low-emissions and resource-efficient econo- } \\
\text { my Part } 1 \text { - Energy/electricity supply audit of enterprises and Part } 2 \text { - Improving } \\
\text { energy efficiency; Improving energy efficiency Part } 3 \text { - Energy efficient invest- } \\
\text { ments in small and medium-sized enterprises; } \\
\text { Supporting projects related to low-emission and resource-efficient economy Part } \\
4 \text { - Energy efficiency in enterprises; } \\
\text { The Operational Program Infrastructure and Environment 2014-2020 (Invest- } \\
\text { ment Priority) - Promoting energy efficiency and use of renewable energy sour- } \\
\text { ces in enterprises; } \\
\text { Regional operational programs for 2014-2020. }\end{array}$ \\
\hline $\begin{array}{l}\text { Measures connected } \\
\text { with energy efficiency in } \\
\text { transport }\end{array}$ & $\begin{array}{l}\text { Green Investments Scheme Part } 2 \text { - GEPARD - Zero-emission public transport } \\
\text { and Part } 7 \text { - GAZELA - Low emission urban transport; } \\
\text { The Operational Program Infrastructure and Environment 2014-2020 (Invest- } \\
\text { ment Priority) - Developing public transport in cities; } \\
\text { Regional operational programs for 2014-2020. }\end{array}$ \\
\hline $\begin{array}{l}\text { Measures connected with } \\
\text { the efficiency of energy } \\
\text { generation and supply }\end{array}$ & $\begin{array}{l}\text { Supporting projects related to low-emission and resource-efficient economy Part } \\
3 \text { - Efficient heating and cooling systems; } \\
\text { The Operational Program Infrastructure and Environment 2014-2020 (Invest- } \\
\text { ment Priority) - Efficient distribution of heating and cooling, - Promoting the use } \\
\text { of high-efficiency cogeneration based on the demand for useful heat, - Efficient } \\
\text { distribution of heating and cooling (Silesia Province) and - Promoting the use of } \\
\text { high-efficiency cogeneration (Silesia Province); } \\
\text { Regional operational programs for 2014-2020. }\end{array}$ \\
\hline
\end{tabular}

Source: NEEAP 2017. 
The Thermomodernization and Repairs Fund is one of important programs in the area of the EE improvement of buildings and serves support for energy saving investments with a thermal upgrading or renovation premium awarded pursuant to the Thermal Upgrading and Renovations Support Act (Act TURL 2008). An owner/manager of a building can use the thermal upgrading premium for reducing annual: energy demand, energy losses, heat acquisition costs or replacing an energy source with a renewable source or using highly efficient cogeneration. An owner/manager of a building can use a renovation premium if the annual demand for energy supplied to a multifamily building for heating and heating domestic hot water is reduced as a result of a renovation undertaking (Act TURL 2008). In Poland, the thermomodernization of buildings includes: insulation of the building, replacement of windows and external doors, replacement of ventilation/air conditioning systems, replacement of heat source or modernization of heating systems, use of RES technologies and use of energy management systems in buildings (Dołęga 2018).

The "Support for enterprises as regards low-emission and resource-efficient economy Part 2 - Improving energy efficiency" Program is one of important programs in the area of the energy efficiency improvement in industry. This measure is financed by the National Fund for Environment Protection and Water Management (NFEP\&WM) and concerns entrepreneurs which undertake energy savings projects and in which the minimum average energy consumption (sum of electricity and heat) was $20 \mathrm{GWh} /$ year (NEEAP 2017). This fund is one of main national sources of funding for programs aiding EE improvement, the development of RES and the modernization or construction (electric power, heat, gas) grid infrastructure (Dołęga 2017). The program measures include: electric energy or heat use rationalization technologies, implementation of energy, quality and network infrastructure management systems in buildings (building complexes) of enterprises and modernization of industrial processes in terms of energy efficiency (NEEAP 2017). Electric energy use rationalization technologies concern: energy efficient engines, compressors and their control systems; energy-saving drive systems and their control systems; pump and fan inverters; in-plant electric energy transmission grid; limitation of reactive power flows in electric energy transmission network; network drive rectifiers; energy transformers with higher efficiency in local power systems and in-plant distribution grids or energy efficient lighting systems. Heat use rationalization technologies concern: RES, including solar collectors, geothermal systems, and heat pumps; thermomodernization of industrial and office buildings; insulation and dewatering of steam systems; heat recuperation and recovery from processes and equipment; refurbishment of internal heating networks; use of energy from waste generated by industrial processes; construction/refurbishment of own (in-plant) energy sources, including cogeneration (Dołęga 2018). 


\section{Energy efficiency of national economy}

The most common energy efficiency yardstick for national economy is the Gross Domestic Product (GDP) energy intensity indicator which means a ratio of energy consumption in tons of equivalent oil (toe) to the GDP of a given country (Dołęga 2017).

An analysis of the energy consumption by the economies of the European Union countries and a comparison with Poland indicates a constant significant gap in this area between Poland and countries like: Germany, France, Spain and the United Kingdom (IEA 2016). This occurs despite the fact that Poland has been made one of the greatest progress in Europe in the EE area since 1990. Moreover, the growth of Poland's GDP is faster than its rate of energy consumption and decrease of primary and final energy consumption is observed.

The consumption of primary energy (a primary energy consumption/GDP ratio) in Poland with a climatic correction, expressed in fixed 2005 prices with the purchasing power parity taken into account, amounted to $0.15 \mathrm{kgoe} /$ Euro05ppp in 2015 and was higher by $15 \%$ than the European average (0.131 kgoe/Euro05ppp) (CSO 2018a). The consumption of final energy (a final energy consumption/GDP ratio) in Poland was at the level of $0.098 \mathrm{kgoe} /$ Euro05ppp and was by $13 \%$ higher than the European average (0.088 kgoe/Euro05ppp) (CSO 2018a). The rate of energy consumption improvement in Poland in the period of 2000-2015 was two times higher than the average in the European Union. It amounted respectively to $3.2 \%$ for Poland and $1.6 \%$ for the average in the EU.

The climate correction takes the relation between energy consumption and outdoor temperature into consideration and is calculated on base of EUROSTAT methodology (Dołęga 2018).

The average rate of the reduction of energy consumption in Poland in the period of 1990-2009, with the climatic correction taken into account, amounted to $3.44 \%$ and $3.92 \%$ for consumption of final and primary energy, respectively (Dołęa 2014). In the years 2010-2016 it amounted to $1.84 \%$ and $2.20 \%$, respectively (CSO 2018b). The level of energy consumption reduction was particularly high in two periods 1993-2000 and 2007-2009. In first period, it amounted to 6.77\% and $7.16 \%$ and in the second period $-4.37 \%$ and $5.25 \%$ respectively (CSO 2018b). The ratio of final energy intensity to primary energy consumption in the period of 2006-2016 is characterized by a growing tendency. The highest value on level of 65.8\% appeared in 2016 (CSO 2018b).

The total primary energy consumption increased in the period of 2006-2016 from 97 Mtoe to 99 Mtoe, with an average annual growth rate on level of $0.2 \%$ (CSO 2018b). Consumption had a growing tendency until 2011, when it reached the highest value in the period of 101.5 Mtoe in 2015 and 2016. The lowest consumption on level of 93.8 Mtoe appeared in 2014 (CSO 2018b).

Final energy consumption increased between 2006-2016 from 61 to 65 Mtoe, with an average annual growth rate on level of $0.8 \%$ (CSO 2018b). In this case, a consumption decrease was observed in the years: 2007, 2009 and 2011-2014. In the case of taking different weather conditions into account, final energy consumption with climatic correction increased in period of 2007-2016 with the same average annual growth rate (0.8\%) (CSO 2018b). 
The industrial sector had a share in the final domestic energy consumption on level of $23 \%$ in 2016. This has significantly contributed to the reduction of energy consumption (CSO 2018a). The industry indicators connected with energy consumption have improved and advantageous structural changes have taken place.

In the period of 1994-2009 the average rate of reduction of energy consumption in Polish industry amounted to $10.43 \%$, but the value of $3.78 \%$ came as a result of structural changes in the industry (Dołęga 2014). In the years 2010-2016 the rate amounted to 3.40\%, 1.30\% of which resulted from structural changes (CSO 2018a).

Primary metals, chemical and non-metallic minerals are energy-intensive industries which dominate in the structure of energy consumption in manufacturing. The total share of these industries in energy consumption in Poland amounted to 53\% in 2016. In 2006, it was a level of $59 \%$ (CSO 2018b). Rates of annual changes of energy intensity of value added in the period of 2006-2016 for these industries was connected with a decrease and shaped by average level of $4 \%$. The energy consumption reduction in the energy-intensive industries has been lower in comparison with the other industry branches. But the primary metal manufacturing represents an exception because of besides the machinery industry, the transport means industry and the textile industry, has shown the highest level of energy consumption improvement dynamics, owing to both an increase in the energy efficiency of industrial processes and the closure of many highly energy-consuming industrial plants, particularly in the 1990s (Dołęga 2014). Most of the improvements introduced by enterprises in the area of the EE resulted from their autonomous decisions and economic calculation. In the 1990s the energy efficiency improvement in many industry sectors was connected with their privatization. This often led to the introduction of new, efficient technologies and modernization of the plants (Dołęga 2018).

The energy efficiency improvement in industry was achieved in Poland through: the development of energy management systems, changes in technology aimed at the reduction of the energy demand, the use of modern efficient technologies and equipment, the development of high-efficiency cogeneration, the re-use of waste energy, introduction of energy audits for enterprises, the introduction of financial support mechanisms towards increasing the share of energy savings for enterprises by using suitable technologies and equipment, the introduction of energy management training programs and the thermal upgrading of industry buildings (Dołęga 2018).

Households had a share in the final domestic energy consumption on level of $30 \%$ in 2016 (CSO 2018a). This has also significantly contributed to the reduction of energy consumption. The consumption of energy per dwelling with the climatic correction taken into account decreased at an annual rate of $1.3 \%$ in the years 2006-2016 (from the level of 1.56 to 1.47 toe/flat), while the energy consumption by households per square metre decreased by $1.9 \%$ /annum (from the level of $23.4 \mathrm{kgoe} / \mathrm{m}^{2}$ to $18.8 \mathrm{kgoe} / \mathrm{m}^{2}$ ) (CSO 2018b). The higher improvement dynamics in the second case have a connection with the increase of average flat size in Poland in this period.

The consumption of electric energy in households per flat in 2016 amounted to $2025 \mathrm{kWh}$ and was lower than in 2006 (CSO 2018b).

The structure of energy consumption in households from the point of end use represented in 2016 was as follows: space heating and ventilation $-66.4 \%$, water heating $-15.8 \%$, cooking 
$-8.0 \%$ and lighting and electric appliances including $-9.7 \%$ (CSO 2018b). The consumption of electric energy by households is determined by many factors, such as the level of prices, the economic situation of households.

The decrease of level of the unit energy consumption in occupied flats is connected with the implementation of the program of the thermal upgrading and renovation of buildings, improvement efficiency of newly installed equipment and a decrease of losses in the heat networks.

Basically, the energy efficiency improvement in households was achieved in Poland through: the utilization of solutions oriented towards the limitation of heat use for heating and water heating purposes, the thermal upgrading and renovation of buildings and the implementation of energy saving features, reduction of generation, transmission and distribution losses, adaptation of the heat supply level to the actual demand, the development of energy management systems in apartment buildings, especially for housing associations and cooperatives and promotion of the rational use of energy in households (Dołęga 2018). The last measure was important in the context of changes in consumer behaviors to more energy-saving ones. The behaviors can be changed by showing the possibilities and benefits of limiting consumption of electric energy (Dołęga 2018).

Thanks to the considerable advances the level of the obtained and planned savings of final energy has exceeded the Directive 2006/32/EC targets which assumed final energy savings at the level of 1.02 Mtoe in 2010 and 4.59 Mtoe in 2016, amounting to respectively $2 \%$ and $9 \%$ of the final energy savings relative to the average energy consumption in the years 2001-2005 (NEEAP 2017). The savings achieved amounted to $10.04 \%$ in 2010 and to $23.29 \%$ in 2016 (CSO 2018a). The amount of achieved savings of final energy in the period of 2010-2016 more than doubled and exceeded the goals set for the years 2010 and 2016.

Despite the significant progress in the limitation of energy consumption and the improvement in energy use efficiency there is still a great untapped potential in this field in Poland. The further reduction of unit energy consumption in scale of the economy is especially important in order to maintain the relatively high economic growth rate in Poland and to achieve a further significant reduction of air pollution and GHG emissions (Dołęga 2018).

Generally, a significant reduction of energy intensity value was obtained through: actions and undertakings relating to the introduction and dissemination of modern highly energy-efficient technologies and equipment, suitable organizational improvements and more rational management.

The improvement in economy energy intensity indicators constitutes the most effective solution. It brings considerable economic benefits and notable environmental effects such as the limitation of consumption of natural resources and a reduction of air pollution and GHG emissions which no results of any other solutions reducing the environmental nuisance of the electric power sector (a change in the energy carrier consumption structure and the construction of protective facilities and installations) can match (Dołęga 2018). Moreover, a reduction of the level of the national economy energy intensity leads to a greater level of energy supply security. Additionally, the investment stimulation towards modern highly energy-efficient technologies and equipment contributes to an increased level of national economy innovation. Thus any effec- 
tive energy saving measures significantly contribute to an improvement in the efficiency of the national economy and to an increase in its competitiveness (Dołęga 2018).

\section{Conclusions}

The energy efficiency increase in area of generation, transmission, distribution and the use of energy constitutes a pillar for pursuing a sustainable energy policy, which is reflected in the national and the European Union regulations, strategies and policies and the actions undertaken by various national and the European Union institutions.

Energy efficiency improvement is of key importance for the achievement of most of the energy, environmental and climate policy goals and so it should constitute a priority in the development and modernization process of the national economy. This improvement can be achieved by, e.g., use of efficient high-performance generation units, reduction of the index of network losses in the area of energy transmission and distribution and an increase of the end utilization of energy.

The Energy Efficiency Act introduces systemic solutions which together with the national, regional and local existing programs and measures related to the improvement of energy efficiency make the increase of the efficiency of the generation and supply of fuels and energy and the utilization of energy by ultimate consumers possible.

Basically, the energy efficiency improvement programs and measures existing in Poland comprise five groups of means: measures having a horizontal nature, and measures connected respectively with the energy efficiency of buildings and public institutions, energy efficiency in industry, energy efficiency in transport, and the efficiency of energy generation and supply. the two national programs (the system of energy efficiency certificates and the Thermomodernization and Repairs Fund) and one European Union program (Infrastructure and Environment Operational Program (Investment Priority) for the years 2014-2020) are especially important.

Over the last years the national economy energy efficiency indicators have improved considerably. Nonetheless, a significant gap in this regard between Poland and the European Union countries such as: Germany, France, Spain and the United Kingdom still remains. Therefore, further relevant measures should be taken in order to bring about further notable environmental-energy efficiency effects.

The improvement in the energy consumption indicators of the national economy brings notable environmental effects (a reduction in the consumption of natural resources and a reduction in the emission of GHG and other pollutants), which the effects of any other solutions reducing the environmental nuisance of the power sector (a change of the energy carriers consumption structure, the building of protection systems and installations, etc.) cannot match. 


\section{References}

Act EEL 2011. Act of 15 April 2011 - The Energy Efficiency Law (Ustawa o efektywności energetycznej) (Journal of Laws of 2011 No. 94, Item 551, with later changes), validity up to 30.09.2016/ (in Polish).

Act EEL 2016. Act of 20 May 2016 - The Energy Efficiency Law (Ustawa o efektywności energetycznej) (Journal of Laws of 2016 Item 831) (in Polish).

Act TURL 2008. Act of 21 November 2008 - Thermal Upgrading and Renovation Law ( $O$ wspieraniu termomodernizacji i remontów) (Journal of Laws of 2008 No. 223, Item 1459) (in Polish).

CSO 2018a. Energy efficiency in Poland in years 2006-2016, statistical analyses (Efektywność wykorzystania energii w latach 2006-2016, opracowania statystyczne). Central Statistical Office of Poland, Warsaw 2018 (in Polish).

CSO 2018b. Energy efficiency trends and policies in Poland in years 2006-2016, national report. Central Statistical Office of Poland, Warsaw, July 2018.

Directive 2006. Directive 2006/32/EC of the European Parliament and of the Council of 5 April 2006 on energy end-use efficiency and energy services and repealing Council Directive 93/76/EEC (O.J.EC L 114 of 27.04 .2006$)$.

Directive 2012. Directive 2012/27/EU of the European Parliament and of the Council of 25 October 2012 on energy efficiency, amending Directives 2009/125/EC and 2010/30/EU and repealing Directives 2004/8/EC and 2006/32/EC (O.J.EC L 315 of 14.11.2012).

BEP 2015. Understanding energy efficiency. Briefing of the European Parliament, October 2015.

DOŁĘGA, W. 2014. Selected aspects of energy efficiency in Poland. [In:] $9^{\text {th }}$ International Conference on Deregulated Electricity Market Issues in South-Eastern Europe DEMSEE 2014, Nicosia, Cyprus, 25-26 September 2014. Section Renewable energy sources and energy efficiency I, full paper 3, pp. 1-5.

DoŁĘGA, W. 2017. Selected aspects of energy efficiency (Wybrane aspekty efektywności energetycznej). Polityka Energetyczna - Energy Policy Journal Vol. 20, Issue 4, pp. 67-78 (in Polish).

DoŁĘGA, W. 2018. Energy efficiency - case study Poland. [In:] 2018 Innovative Materials and Technologies in Electrical Engineering (i-MITEL), 18-20 April 2018, https://doi.org/10.1109/IMITEL.2018.8370463, pp. 1-6.

EPP 2010. Announcement of Ministry of Economy from 21.12.2009 in a matter of the national energy policy up to 2030 (Obwieszczenie Ministra Gospodarki z dnia 21 grudnia 2009 r. w sprawie polityki energetycznej państwa do $2030 \mathrm{r}$.) (Monitor of Poland of 2010 No.2, Item 11) (in Polish).

EPP 2018. Energy Policy of Poland until 2040 (PEP2040) (Polityka energetyczna Polski do 2040 roku). Ministry of Energy, Warsaw 2018 (Draft v.1.2-23.11.2018) (in Polish).

IEA 2016. Energy Efficiency Indicators, Highligts 2016. International Energy Agency, Paris, December 2016.

NEEAP 2014. National Energy Efficiency Action Plan for Poland 2014 (Krajowy Plan Działań dotyczacy efektywności energetycznej dla Polski 2014). Ministry of Economy, Warsaw 2014 (in Polish).

NEEAP 2017. National Energy Efficiency Action Plan for Poland 2017. Ministry of Energy, Warsaw 2017.

Report PERO 2019. Report of activity of the President of Energy Regulatory Office in 2018 (Sprawozdanie z działalności Prezesa Urzędu Regulacji Energetyki w 2018 r.). Energy Regulatory Office, Warsaw, April 2019 (in Polish). 


\title{
Wybrane aspekty efektywności energetycznej gospodarki krajowej
}

\begin{abstract}
Streszczenie
W artykule przedstawiono problematykę efektywności energetycznej. Omówiono unijne i krajowe regulacje prawne dotyczące efektywności energetycznej. Zwrócono szczególną uwagę na dyrektywę 2012/27/EU i ustawę o efektywności energetycznej. Przedstawiono zasady realizacji obowiązku uzyskania oszczędności energii oraz przeprowadzania audytu energetycznego przedsiębiorstwa. Przedstawiono programy i środki służące poprawie efektywności na poziomie krajowym, regionalnym i lokalnym. Zasadniczo obejmują one pięć grup środków: o charakterze horyzontalnym; w zakresie efektywności energetycznej budynków i w instytucjach publicznych; efektywności energetycznej w przemyśle; efektywności energetycznej w transporcie oraz efektywności wytwarzania i dostaw energii. Przedstawiono problematykę efektywności energetycznej krajowej gospodarki. Przeanalizowano wskaźniki energochłonności pierwotnej i finalnej oraz tempo ich zmian w ostatnich latach. Określono kierunki działań, które pozwolą na dalsze zmniejszenie energochłonności krajowej gospodarki. Przedstawiono analizę działań i rozwiązań umożliwiających poprawę efektywności energetycznej, zwracając szczególną uwagę na sektor przemysłu i gospodarstwa domowe. Poprawa wskaźników energochłonności gospodarki stanowi najbardziej efektywne rozwiązanie, które obok znacznych korzyści ekonomicznych przynosi wymierne efekty ekologiczne (zmniejszenie zużycia przyrodniczych zasobów, zmniejszenie emisji zanieczyszczeń), zwiększenie bezpieczeństwa dostaw energii, wzrost innowacyjności gospodarki i jej konkurencyjności. Wnioski zawieraja analizę obecnego poziomu efektywności energetycznej w kraju i perspektyw jego wzrostu w przyszłości oraz korzyści z tym związanych.
\end{abstract}

SŁOWA KLUCZOWE: gospodarka, efektywność energetyczna, energochłonność, polityka energetyczna 
